\title{
A experienciação da morte na poesia de Max Martins
}

\author{
The experience of death in Max Martins'poetry \\ Natália Lima RIBEIRO* \\ Universidade Federal do Pará (UFPA) \\ Antônio Máximo FERRAZ** \\ Universidade Federal do Pará (UFPA)
}

\begin{abstract}
RESUMO: Este trabalho propõe a interpretação da questão da Morte na poesia de Max Martins, entendida como plenificação humana. Hoje, a Morte reduziu-se a conceitos, e passa, comumente, a não mais ser vista como questão que provoca o pensamento. Isto ocorre em função do esquecimento da questão do Ser, o qual caracteriza nossa era. Paralelamente, o questionar e o pensar foram engessados devido à interpretação da tradição metafísica sobre o real. Porém, em Max Martins, principalmente na obra $O$ estranho (1952), por meio do exercício da memória e do relembrar dos mortos, o homem pode novamente vislumbrar seu destino e questionar-se sobre este fenômeno constitutivo da existência. Assim o fazendo, a experiência da Morte passa a ser vista como o télos da vida, a plenificação da existência humana. Para o desenvolvimento deste trabalho, propomos um diálogo, entre outros, com os pensadores Martin Heidegger (2012) e Heráclito de Éfeso (1991).
\end{abstract}

PALAVRAS-CHAVES: Max Martins. Morte. Memória.

ABSTRACT: This paper proposes the interpretation of the question of Death in the poetry of Max Martins as human fullness. Today Death became a concept, and the questioning of this phenomenon is not contemplated. This concept comes from the forgetfullness of the question of Being, which characterizes our time. At the same time, the question and thinking were plastered due to the interpretation of the metaphysical tradition of the real, but in Max Martins, especially the work $O$ estranho (1952), through the exercise of memory and remember the dead, man can again glimpse the fate and wonder again. Thus, the death experience is the télos of life, fullness of human existence. Therefore, we propose a dialogue with the works of the thinker Martin Heidegger (2012), and the poet Heraclitus of Ephesus (1991).

KEYWORDS: Max Martins. Death. Memory.

Recebido em 3 de outubro de 2016. Aprovado em 28 de novembro de 2016.

\footnotetext{
* Mestranda em Estudos Literários pela Programa de Pós-Graduação em Letras, na Universidade Federal do Pará. Bolsista CNPq. E-mail: natalia.limar21@ gmail.com

** Professor Adjunto do Instituto de Letras e Comunicação da Universidade Federal do Pará e do Programa de Pós-Graduação em Letras na mesma Universidade. Doutor em Ciência da Literatura pela Universidade Federal do Rio de Janeiro, na área de Teoria Literária, com a tese "Fernando Pessoa em obra: a teatralização da metafísica". Mestre em Teoria Literária pela Universidade de Brasília, com a dissertação "O sagrado no 'Retábulo de Santa Joana Carolina', de Osman Lins". Bacharel em Direito pela UnB e advogado. É um dos coordenadores da Rede Poética - Grupo Interinstitucional de Pesquisas em Arte e Filosofia, grupo que reúne pesquisadores de diversas universidades brasileiras. Coordena o Núcleo Interdisciplinar Kairós - Estudos de Poética e Filosofia (NIK/UFPA). E-mail: maximoferraz@gmail.com.
} 


\section{Introdução}

Neste trabalho, propomos realizar uma interpretação de como Max Martins pensa a Morte em sua poética. Assim, partimos da convicção de que esse acontecimento intrínseco à vida constitui um fenômeno que não se pode confinar em um conceito ou paradigma. Contudo, observamos que a experiência existencial comumente é vivida por segmentações e ideologias. As questões ${ }^{1}$ não são pensadas originariamente ${ }^{2}$. $\mathrm{O}$ aprisionamento aos conceitos exaure do homem a capacidade de pensar e de questionar a realidade. Max Martins, ao longo de sua odisseia poética, percebe-se como homem que a todo o momento procura se libertar do mundo dos conceitos, imunizando-se com palavras que resgatem o vigor poético da linguagem e do humano. Percebemos isso em poemas como "Os anos deste dia", da obra Colmando a lacuna (2001):

Calar também o lado só
de estar
De agora estares
a cuspir o gosto
de despojo
de tua alma
quente
na tua boca
o alto mar fala
desfalecendo
neste velho dia
como um cão
do fundo

\footnotetext{
${ }^{1}$ Segundo Antônio Máximo Ferraz (2010, p. 4-5), "a palavra 'questão' possui a mesma procedência do verbo 'querer'. 'Questão' vem de quaestionis, que significa 'busca', 'procura'. 'Querer', por sua vez, vem do verbo quaerere, que igualmente significa 'buscar', 'procurar'. Ambas as palavras - 'questão' e 'querer' - provêm do verbo queror, que significa "soltar gritos de lamentação, gemer, suspirar, murmurar, sentir". Perguntamos: quando alguém sente algo - e por isso se lamenta, grita e geme -, o faz porque decidiu sentir ou porque foi tomado pelo sentimento? Quando alguém se apaixona, o faz porque decidiu se apaixonar ou porque foi invadido pela paixão? Ora, quem grita, geme ou se lamenta é invadido pelo sentimento (páthos), por algo que nele se manifesta, mas que o excede, porque não foi ele quem decidiu sentir. Sentir não é ato da deliberação humana, porque o sentimento, em que as questões se manifestam, nos arrasta”. Dessa forma, as questões não podem ser entificadas ou assolapadas por conceitos. Elas constituem o que é além do humano e sua vã filosofia colonizada.

${ }^{2}$ Segundo Manuel Antônio de Castro (2004, p. 19), "não podemos confundir o conceito metafísico de origem com a questão do originário. A origem é causal e linear. $\mathrm{O}$ originário não. Ele é como a fonte que alimenta sempre o rio, esteja em que altura estiver a sua correnteza, da nascente à foz. Originária é a Terra, que sempre é a permanente fonte de toda vida e de todos os viventes, inclusive nós seres humanos. Originária é a mulher-mãe ao conceber, gestar e dar à luz um filho. Entre a primeira mulher que deu à luz um filho e a que hoje dá à luz um filho não há diferença nenhuma do ponto de vista de ser mãe-mulher. A mãe-mulher é sempre originária”.
} 
do fundo de si mesmo

exausto

(MARTINS, 2001, p. 71).

No poema, como aponta o título, o tempo é uma máquina que conta os anos dentro de um dia enfadonho. O poeta calcula o tempo da jornada de trabalho, do fim do dia - que passa em lentidão. Dentro desse dia, a vida desfalece, haja vista que não é consumado o pensar, o questionar, que cada momento diário possibilitaria se estivéssemos no vigor de uma experiência ontológica da vida. Estar calado não nos remete a uma experiência originária de escuta: ao contrário, o calar nos remete ao não questionar, nesse poema. Estar calado também é permanecer passivo aos ditames sociais em que nada se cria. O homem torna-se máquina, o tempo apenas esvazia a vida aos poucos, a conta-gotas. Há na operação poética um descontentamento com essa maneira de viver. O gosto "amargo", no qual a alma das coisas se perde, transforma-se em náusea, resposta do próprio sistema digestivo a essa maciça experiência de viver segundo padrões - "De agora estares /a cuspir o gosto /de despojo /de tua alma/quente /na tua boca". Ademais, essa reação negativa ao cotidiano transmuta-se na alma. Na realidade, corpo e alma inscrevem-se na mesma ação, não há uma cisão entre eles. A alma é o vento que tudo põe em dança, lúdus, no pólemos entre o Ser e os entes, entre o Ser e o homem.

\section{O cotidiano e o pensamento}

Ao ser banida como questão nesses dias de instrumentalização da linguagem, a fala se perde, como podemos notar quando o poeta diz: "o alto mar da fala/desfalecendo". O alto mar da fala é a linguagem criativa que se perde na vida cotidiana. Muito se fala sobre Amor, Morte, Tempo, a ponto de existir um discurso prontamente mecanicista a favor do não questionamento de tais fenômenos. Max Martins mostra o pensamento que, na Era Moderna, o mundo não é sua morada primordial, de maneira que há uma crítica a esse modelo de vida que nos é imposto diariamente:

Ocorre-me o poema.

Contudo há a religião 
A pátria, o calor.

Procuro ver na noite profunda

Quero esquecer no momento

Que sou o homem de vários documentos.

Forço.

Dói-me o calo desta vida "meu Deus"...

Lavo as mãos;

Mas tenho que pôr a gravata,

E salvo a moral. Abano-me.

Rola o poema e o mundo.

E eu mudo

(MARTINS, 2001, p. 363)

Nas obras $O$ estranho e Anti-retrato, a passagem do tempo e a melancolia da Morte apresentam-se de maneira mais acentuada do que em suas obras posteriores. Além disso, há uma operação evidente que congrega o homem, sua cotidianidade e a vontade de se libertar desse mundo: "Ocorre-me o poema./ Contudo há a religião/ A pátria, o calor". Percebemos que o homem, na modernidade, está preso a um sistema social que tende para a padronização do pensamento. Sendo assim, o poético ("Ocorreme o poema") vigora em todos os seres, porém não é vivido por causa da impregnação de conceitos que circunscrevem o âmbito cotidiano da vida à mera praticidade. $\mathrm{O}$ poeta procura na natureza, a qual se vela e desvela na escuridão, as questões apontadas nestes versos: "Procuro ver na noite profunda/ Quero esquecer no momento/ Que sou o homem de vários documentos". Assim, há um deslocamento para fora dos limites paradigmáticos a respeito do que se entende por vida - ou o que se pensa que ela é.

A "força" de experienciar" a vida fora da cotidianidade acontece dentro da poesia maxmartiana, como percebemos no acima citado "Poema". Além da construção

3 A palavra experienciação abarca a ação verbal do que é a travessia. Essa palavra é constituída pela partícula peras, oriunda do indo-europeu. Desta raiz nasceu a palavra perigo, passar entre, caminhar até o fim. E o prefixo ex, o qual remete ao movimento para fora, ir além dos limites, em direção ao horizonte. Dessa forma, experienciar é o mover-se para fora, em posição de perigo, auscultando o que não se pode apreender. Experienciar é estar em conformidade com o mundo, ser regido pelas questões e transformarse. Fazer a experienciação do mundo é adentrar os abismos e sair dos limites, assim como mostra-nos Heráclito no fragmento 14 , pois os que fazem o transcurso da vida no grande aberto das questões estão 
metafísica ${ }^{4}$, pautada em uma tradição humanista ${ }^{5}$ e mimética, essa vida cotidiana é também responsável pelo encobrimento do Ser. Porém, como nos mostra o poeta paraense, somente a poesia consegue extrair o sumo da vida, já que dentro da poética o homem encontra-se no movimento que é proporcionado pela existência. Em Colmando a lacuna, última obra do poeta, há marcas de uma luta contra esse exaurimento proposto pela rotina mecanicista da vida:

(...) A passeante lembrança com olhos
e dedos folheando o diário
teu diário que um dia foi tão nosso
poema
sumo que tento sorver o mais
que posso
colmando a lacuna, o buraco
cada vez mais fundo
que a distância cavou dentro de mim (...)

(MARTINS, 2001, p.51).

No diário há uma tentativa de sistematizar o dia em eventos. Dentro dessas páginas, não há indícios de uma vida desgastada pela lida cotidiana. Na verdade, dentro dessa vida em plenitude, o diário é um instrumento para nascer poesia. Na tentativa de fechar a dor e encher o "buraco" em que o cotidiano desvela ao homem moderno, o poeta preenche-se de poesia para tentar ao máximo "sorver" o tutano da vida. Porém, esse vazio não se enche e cada vez fica mais fundo, pois aí já temos o nada, este nada de

próximos do perigo que é o mistério: "Para errantes noturnos, os magos, as mênades, os mistas. (...)É sem piedade que se iniciam nos mistério em voga entre os homens" (HERÁCLITO, 1991, p. 61). Dessa forma, experienciar a Morte em Max Martins é estar para fora das consumações modernas, aproximar-se do mistério e acolher a humanidade.

${ }^{4}$ Em linhas gerais, a tradição metafísica é uma visão de que o conhecimento é um compêndio de conceitos, ensinado dentro de uma lógica objetiva. A interpretação vigente do real, da natureza e do homem busca instrumentalizar e converter tudo em recursos naturais e humanos. Como consequência, transforma tudo em objetos, engessando as questões e o Ser. É o que podemos ver na interpretação vigente sobre a questão do Amor: temos um conceito de amor, vendido pelos meios de comunicação, em detrimento do seu sentido ontológico.

${ }^{5}$ Por tradição mimética, entenda-se a concepção da arte como cópia. Ela vem a ser o correlativo, em arte, da tradição metafísica, que, na resposta à pergunta sobre o Ser, o entifica, reduzindo-o a um ente. E o Amor não é um mero ente, mas uma abertura ao questionar. A tradição ontoteológica, como o nome diz, é aquela que concebe o Ser como Deus, reduzindo a pergunta sobre o Ser - e consequentemente sobre o Amor - à esfera de uma tradição religiosa. Mas, se o Amor coubesse em um conceito, se fosse um mero fato e não um permanente por-fazer, não teríamos diversas interpretações dessa questão, pelos mais diversos pensadores e poetas. 
que tudo floresce e que incendeia a poesia. Na modernidade o nada é algo sem valor, porém, em Max Martins, é o mais alto saber que o homem pode ter.

Assim, em nossa época o homem "sabe" demais, há nele conceitos em excesso e o saber é impregnado por um falatório ou se entrega a ideologias que restringem o pensar a paradigmas que apresentam formas prontas da realidade. Porém, o saber está no não saber, é a procura de ver na escuridão da noite profunda:

Saber

Todas as portas estão abertas

Ou não há portas

(MARTINS, 2001, p. 57).

Para o poeta, o saber é encontrar-se diante das diversas possibilidades engendradas pelas questões. Saber é percorrer o perigo que é a vida, imerso na escuridão e na possibilidade de perscrutar novos horizontes de realização. A vida em Max Martins dispõe-se como acontecimento, fenômeno, e não como o cotidiano que encobre essa matéria pulsante e inominável. Em diálogo com o poema, dentro da esfera de domínio da tecnociência em que o século XX emergiu - e o século XXI também -, toda e qualquer experiência poética é tida como fantasia, irrealidade. Dessa forma, "as portas" foram fechadas, e há somente uma chave mestra que poderá abrir a todas: a poesia.

\section{Na plenitude da vida: a morte}

Percebemos um enquadramento da questão da Morte, a qual não vigora em suas diversas "portas" ou possibilidades de interpretação. Temos uma ideia um tanto restrita sobre o que é a Morte, pois, na era da tradição metafísica, ela foi aprisionada em um conceito. Devido a isso, o esquecimento da Morte como questão cobriu-a de uma carga funesta e é representada apenas como o fim existencial. Porém, o que significa fim? Na experiência grega, lugar do berço da civilização e do pensamento ocidentais, a palavra fim é dita no vocábulo télos. O termo grego significa levar algo à sua plenitude ou também a urgência de chegar, potência máxima de realização para a consumação final, colocando-se em consonância com o destino. Segundo Leandro Gama Junqueira, "destinar-se é manter-se no aberto em correspondência do movimento de télos" (JUNQUEIRA, 2014, p. 234). O fim, então, não seria um cessar da ação, mas um 
manter-se no limite da ação do destino, ao abarcar a abertura de consumação existencial, correspondendo ao apelo do Ser. Na analítica do ser-aí, proposta por Martin Heidegger, uma das estruturas de realização humana é o ser-aí-para-a-morte. Ao atingir esse horizonte de experienciação humana, o ser-aí tem sua plenitude e confirmação existencial. Emmanuel Carneiro Leão explicita essa plenitude na esfera da experiência grega:

Costuma-se traduzir télos por meta, fim, finalidade. Todavia, télos não diz nem a meta a que dirige a ação nem o fim em que a ação finda, nem a finalidade a que serve a ação. Télos é o sentido, enquanto sentido implica princípio de desenvolvimento, vigor de vida, plenitude de estruturação. Assim o télos, o sentido de toda ação, é consumar a atitude, é o sumo desenvolvimento do vigor de sua plenitude. Atitude, como a consumação de todos os sentidos das ações, to teleio taton, é pois, a perfeita integração de penhor e bem (LEẪO, 1992, p. 156).

Ao percebemos que o fim significa a plenitude em seu sentido originário, é preciso pensar sobre o que é esse morrer. A Morte, em um dos relatos mitológicos da Grécia Antiga, encontra-se expressa na figura de Thánatos. Filho de Nix, personificação e deusa da noite, Thánatos tem a origem etimológica do indo-europeu dhwen, que significa dissipar-se, torna-se sombra. Em seu sentido originário, a Morte "significa ocultar-se, ser como sombra" (BRANDÃO, 1991, p. 399). Thánatos é o fim de um ciclo, uma descontinuidade, uma cisão, e não um mal. Ao percorrer o caminho do pensamento ontológico, Martin Heidegger mostra como a Morte se realiza na angústia. Nela, a vida se essencializa como uma questão, remontando ao caráter enigmático da Morte. Segundo Junito Brandão, a Morte é a fonte da angústia na Grécia Antiga, de forma que sua personalidade não foi antropomorfizada, permanecendo em mistério quanto a sua fisionomia. Thánatos "apresenta-se sob forma de nuvem escura, de uma bruma, que se derrama sobre os olhos e a cabeça do moribundo. É um véu negro que se interpõe entre o homem e a luz" (BRANDÃO, 1991, p. 399).

A figura originária da Morte, na alegoria de Thánatos, de acordo com Junito Brandão, é a passagem, o entre-lugar entre o humano e o divino, fonte de angústia e de incertezas suplantadas pelos mistérios que circunscrevem uma experiência existencial no seio do questionar. A morte seria uma iniciação para uma nova fase, uma nova vida. Sendo assim, a Morte leva a experiência humana para o seu télos, sua plenitude, para a o nascer contínuo das coisas, pois "a Morte não é um fim em si; ela pode nos abrir 
portas para o reino dos espíritos, para a vida verdadeira: mors ianua uitae, a morte é a porta para a vida" (BRANDÃO, 1991, p. 400).

Ao notarmos que a experiência grega propunha um caráter de mistério e angústia para a Morte, podemos perceber uma cisão profunda dessa questão, que na era moderna se tornou conceito. O aprimoramento da técnica e de uma cultura antropocêntrica reduziu as questões existenciais a conceitos generalizantes, um paradigma social velado por uma construção humanista. $\mathrm{O}$ homem é aquele que possui a dádiva do mistério, ele é doação e já está lançado na experiência da Morte em toda sua travessia existencial. A cotidianidade instaura o esquecimento do luto e a banalização da experiência da Morte, subtraindo dessa experienciação a plenificação que o télos proporciona.

A cisão provocada pela centralização do poder da Igreja, na Idade Média, foi se tornando um dos vetores para a propagação de uma conceitualização e separação da Morte e do cotidiano. A Igreja Católica tornou-se autoridade e gestora dos rituais funestos. Segundo Aleida Assman, a Morte torna-se, no período que corresponde à Idade Média, uma aliada para a doutrinação cristã, que aprisionou essa experiência em uma dualidade (o mundo dos vivos e dos mortos):

\begin{abstract}
A instituição do banquete era muito difundida no mundo romano e no início da era cristã, até que a Igreja, sob o bispo Ambrósio, no século IV, reprimiu as formas familiares de culto aos mortos em favor de uma forma centralizada. Os festejos familiares para os parentes mortos foram substituídos pela memoração coletiva de mártires, cujos ossos eram levados às igrejas locais. No lugar do banquete fúnebre particular, em ambiente familiar, a nova forma de socialização passou a ser a ceia comum na paróquia (ASSMAN, 2011, p. 38).
\end{abstract}

Ao ser instituída uma autoridade sobre a Morte e seus ritos, a conceituação e a separação entre um mundo dos mortos e um dos vivos tornaram-se patentes, além da cisão entre mortais e imortais. Na vigência do originário, na Grécia Antiga, os mortais e imortais ainda atravessavam o mesmo espaço, a terra. Porém, com o advento da Igreja Católica, a ideologia construída por essa instituição tornou-se a intercessora ou o agente do divino no mundo.

Posteriormente, no século XVIII, o culto aos mortos na Idade das Luzes já se encontrava sem nenhum saudosismo ou nostalgia, como uma maneira de esquecer o passado e sempre olhar para o futuro. Nesse período, como afirma Jacques Le Goff (1992, p. 461), “a comemoração dos mortos entra em declínio”. Dessa maneira, os 
locais em que existem referências à recordação dos mortos, como os cemitérios, entram em decadência, levando a um esquecimento dos que ali jaziam, pois "antigamente lembrava-se, em cada ano, a memória dos defuntos” (LE GOFF, 1992, p. 461). Essa mudança da atitude em relação aos mortos aconteceu devido ao pensamento iluminista ter como intuito o desaparecimento de dúvidas ou incertezas abstratas.

O legado advindo destes conceitos de uma construção do mundo edificada em paradigmas acarretou o pensamento da Morte apenas como fim, apenas na esfera subjetivista, ditada pelo homem. Entretanto, esse constructo sobre a Morte é mais um marco da consumação metafísica, mas não a metafísica em seu sentindo originário. $\mathrm{O}$ homem, na metafísica originária, é o homem dentro da natureza, das questões e das coisas, não perante e maior do que tudo: o prefixo metá significa "entre”, ou seja, dentro da phýsis $^{6}$. Esta, traduzida atualmente apenas como natureza, significa originariamente o brotar contínuo, o fazer nascer (phyo), o brilhar (phao), a luz (phos). Essas possibilidades de evocação que a palavra phýsis congrega foram esquecidas para tornála apenas uma tradução que não traz a potência do vocabulário grego.

O esquecimento da Morte e da natureza como questões chegou a seu extremo com o advento da Idade Moderna, já que o pensamento da tradição antropocêntrica se estruturou de maneira radical a partir dessa era. Segundo Andrea Leitão,

A perspectiva antropocêntrica colocou-se em uma posição supostamente privilegiada no propósito de abarcar o real em sua totalidade, no entanto fragmentando-o nos diversos campos científicos. Todo o empenho humano esteve em instituir, no auge de sua pretensão, definições, delimitações e representações sobre questões que atravessam o homem e a sua experiência no mundo, acreditando esgotá-las em teorias conceituais universalizantes (LEITÃO, 2015, p. 31).

\footnotetext{
${ }^{6}$ A phýsis, palavra grega antiga que costuma ser traduzida por natureza, é mais do que isso. Por natureza, entendemos o conjunto de coisas que se acham fora da cultura, por isso mesmo alvo de representação das assim chamadas "ciências naturais". A cultura, essa sim, diria respeito, na representação moderna, ao homem. A phýsis, no entanto, é o manifestar contínuo da totalidade das coisas, velando o que efetivamente são, pois estão em movimento, de modo a velar o seu Ser, a sua arkhé. É o velamento da phýsis a fonte de todo o questionar, inclusive da possibilidade de o homem questionar o seu próprio ser, pois ele também é phýsis (no mundo grego antigo, o conhecimento não estava separado entre natureza e cultura, como na representação da era moderna). A existência humana, de maneira originária, está integrada à dinamicidade da phýsis, a qual é a fonte de todo questionar.
} 
Em tempos de penúria para o pensamento, as experiências de essencialização do homem no mundo solapam a experiência originária dos gregos. $\mathrm{O}$ antropocentrismo acentuado, a vivência cotidiana e o esquecimento do ser instauram um enrijecimento do pensamento, indiferença frente ao outro e à Morte. Além disso, há o esquecimento da memória e dos que morreram, pois tal tradição encontra-se em declínio desde a Era Moderna. A rememoração a partir da morte é recorrente na história ocidental como uma maneira de perpetuar a cultura e a sabedoria de um povo, porém estes ritos encontramse na esfera do espiritual, não como horizonte de abertura ao questionar.

Ao fundar-se uma era da racionalização e de domínio da ciência sobre o pensamento, começa a ser retirada do homem sua realização emancipatória de ser questionador, já que a ciência se define como domínio das respostas universalizantes do mundo. Assim como o Amor, a Morte encontra-se no horizonte do questionar, no seio do mistério da phýsis e do ser. Ao levar o ser ao esquecimento, nega-se a Morte como constitutiva do horizonte de realização existencial, o lugar do questionar e do experienciar a vivência humana em seu télos originário.

Como poeta que questiona e faz da sua poesia uma morada do pensamento ontológico, Max Martins mostra-nos novamente a Morte em seu vigor de experiência dinâmica. Em sua primeira obra, O estranho, de 1952, há várias elegias. A Morte, nela, aparece como um fenômeno que, ao levar o homem à sua plenitude, aproxima o humano do ser, já que é apenas como fenômeno ou evento que é possível sua experienciação, como afirma Alfredo Bosi:

O grande mar do ser, que a consciência poética só consegue penetrar quando lhe é dado sob as espécies do evento. $\mathrm{O}$ evento, aquilo que me sobrevém, a mim e em mim, constitui-se como uma experiência significante do sujeito, vivência aberta e múltipla e que a forma só aparentemente encerra nos signos e símbolos (BOSI, 2003, p. 464465).

A carga funesta emprestada à Morte quando entendida somente como fim da vida retira o traço questionador sobre a existência. Isto é, o caráter da Morte como confirmação da existência, apontado por Martin Heidegger (2012a), não é percebido devido ao subjetivismo em que se funda a Era Moderna. A sociedade encara o fim da vida apenas como um evento triste, não como abertura para o pensar. Um poema que vislumbra a Morte como lugar para o questionar e a poética como lugar da experiência desse fenômeno é "Elegia III", oriundo do livro O estranho, de 1952: 
Nenhum pássaro na manhã cantou o teu soluço.

Calço os teus sapatos (mas o teu silêncio como dói)

E com eles caminho meio mundo inutilmente:

Faltam os teus passos

E a tua voz imperturbável.

Resta o guarda-sol

Mas me falta o jeito de carregá-lo

E a sombra.

Se cinco anos andei com teus conselhos

Agora estou só com tua camisa.

Deixaste uns gestos tristes nos espelhos

Com uma imensa interrogação à minha filha

E muitas vezes é o teu próprio riso que trazem até as cadeiras da varanda.

Hoje o mundo corre abaixo de teu retrato

(MARTINS, 2001, p. 366).

A Morte é interpretada na conjuntura moderna apenas como um evento de lamentação e luto. Max Martins vai além, ele propõe uma interpretação desse fenômeno como questionamento da finitude humana; superando, assim, a ideia do homem como medida de todas as coisas; mostrando a essência finita do homem, pois sua condição de homem o torna pequeno perante a natureza (phýsis).

Comecemos a interpretação pelo título. Elegia tem em sua origem o termo grego "elegueia" ( $\left.\dot{\lambda} \varepsilon \gamma \varepsilon \varepsilon^{\prime} \alpha\right)$. A palavra caracteriza o verso em dístico elegíaco, com temáticas que abordavam vários assuntos, entre eles a Morte. Elegias apresentam um tom triste e suave. Algumas eram feitas para a construção de epitáfios de túmulos. Seu significado original no poema de Max relaciona-se com a expressão grega.

O poema tem dois campos lexicais principais: objetos e ações. Os objetos representam o que restou, materialmente, do ente que partiu. Eles são representados pelas palavras "sapatos", "guarda-sol", "camisa", "espelhos", "cadeiras" e "retrato". As ações que são feitas pelo sujeito do poema utilizam-se dos objetos supracitados para a permanência do ente que se foi. Esse homem usa os "sapatos" e a "camisa" para rememorar a presença do morto. 
No segundo verso, "Calço os teus sapatos (mas o teu silêncio como dói)", esse sujeito utiliza o sapato de alguém já falecido, o que restou dele. A dor do silêncio representa a saudade, égide da rememoração de uma elegia em tons funestos. O homem continua utilizando-se dos objetos do pai; tentando, assim, perdurar a existência do outro nele ou buscando a permanência da figura paterna. $\mathrm{O}$ que denuncia uma relação de parentesco é o verso: "Deixaste uns gestos tristes nos espelhos". Ao olhar a superfície espelhada, o sujeito do poema vislumbra a imagem do homem morto, sugerindo uma semelhança entre os dois. Essa semelhança também pode ser interpretada nos "gestos tristes" deixados no espelho, os quais podem ser compreendidos como a saudade e o luto; sugerindo, assim, uma relação parental.

Ao longo da tessitura poética, o ambiente funesto e a saudade perduram. Nos versos "Resta o guarda-sol/ Mas me falta o jeito de carregá-lo", novamente o homem depara-se com algo que lembra a pessoa a quem é dirigida a elegia. Tenta, outra vez, apropriar-se do objeto, pois, de certa forma, procura resgatar por meio da memória o jeito do falecido.

Percebemos que o homem intenta ao longo do poema descrever uma maneira de apropriar-se da identidade do outro, do possível pai falecido, por meio dos objetos deixados. Como consequência, na perda ele agoniza entre ser quem é e a influência do possível pai em sua constituição como homem; aproximando-se, assim, do questionar existencial no qual a Morte lança o ser humano, sua condição mais essencial, o que permanece e que é irremediável. É retratada no poema a permanência

No último verso, "Hoje o mundo corre abaixo de teu retrato", o poeta constrói a imagética da Morte enquanto fenômeno necessário para a evolução e a continuação do fluxo da vida. Heidegger ressalta que "no morrer dos outros se pode experimentar o notável fenômeno-de-ser que deve se determinar como a mutação de um ente a partir de um modo-de-ser do Dasein (ou da vida)" (HEIDEGGER, 2012, p. 659). O homem no poema depara-se com o fenômeno-de-ser na Morte por meio da experiência do outro, plasmando a experenciação da Morte no poema.

A Linguagem é a morada do Ser, nela é possível, então, experimentar o fenômeno da Morte. A poesia, consequentemente, seria um lugar em que o homem pode se questionar e ter a dimensão desse fenômeno-de-ser. A experiência da obra de Max é uma travessia poética para a essência do questionar e do pensar. No poema, a temática 
da Morte não é construída apenas de maneira funesta. O homem tem na morte a confirmação de sua existência, um espaço para o ser humano perceber-se ínfimo, rompendo o pensamento de que o homem é força fundadora de tudo e de todos. Em "Elegia em junho", é possível inferir a conscientização de homem transitório, temporal, que vislumbra a todo o momento no transcurso da vida:

Só com tua memória

Há uma casa no vale.

Estou contando os passos na varanda

- A faca corta o pão separando o tempo em nós -

Mas o relógio continua

Nos teus sapatos cresceram flores de limo

Verdes e brancas,

Ninguém toca nas rosas em teu louvor.

A sala está simplesmente vazia

Como o teu espelho

Hoje só minha filha não te conheceu

Pensa que morreste.

Ninguém saberá que a vida se estagnou no vale.

De longe se vê a chaminé que transpira

O que tu foste

E és

(MARTINS, 2001, p. 365).

Ao adentrarmos no esquecimento do ser e na restrição da Morte em conceito, é possível notar que tal fenômeno se relaciona de modo plausível com o declínio da rememoração dos mortos e dos ritos de passagens. Em "Elegia em junho", Max encontra na Morte e na memória uma dobra para a tessitura de suas elegias. Dessa forma, o elemento mnemônico perpassa por toda a tematização da Morte em sua obra, que fica flagrante em "Só com tua memória/Há uma casa no vale”. A memória é a forma de recordar e de viver o luto e, ao passar pela sombra de Thánatos, o questionar passa a vigorar. Tal memória encontra-se no télos da vida e do poema, no "vale" há a moradia primordial. O vale é o interlúdio entre duas montanhas, dois pontos mais altos, dois 
télos. O vale representa a existência oriunda de um intervalo e da vigência constante do aproximar-se do destino. Essa simbologia denota o caráter evidente da memória como retorno ao vale da vida, ao jogo ontológico em que o homem está lançado.

Há ao longo do poema também alegorias e símbolos que remetem ao findar contínuo das coisas, abertas para a existência, assim como em "Elegia III". Apesar da Morte, as coisas permanecem em constante transformação, como podemos ler no trecho: "Mas o relógio continua/ Nos teus sapatos cresceram flores de limo". Assim, o brotar contínuo permanece, o tempo continua em sua dinâmica e o mundo está sempre em seu devir. Devido a isso, a Morte permanece no contínuo mistério em que o homem se angustia e torna-se questionador.

Martin Heidegger propõe que a Morte e a angústia são intrínsecas ao ser-aí, lançado no mundo, fora da cotidianidade. Diante disso, propomos que, na obra de Max Martins, a Morte encontra-se disposta em uma tríplice aliança com a memória e a angústia. Ao se deparar em com o fenômeno da Morte, o ser-aí angustia-se e chega ao télos de sua existência, sendo que a memória é a marca da essencialização da vida, pois é o retorno ao passado e a confirmação da existência.

Desse modo, a poesia, em coexistência com a memória, é a possibilidade de experienciar a Morte na dinâmica primordial, em marcha na direção de uma superação da edificação da Morte na esfera do conceito e do ritual preponderantemente religioso. A rememoração e a Morte levam a existência aos horizontes de possibilidades da força do pensar e questionar de maneira emancipatória e própria de cada ente. Além disso, Heráclito (1991, p. 75) aponta que a Morte sempre se mostra aos mortais em constante devir: "Imortais mortais, Mortais Imortais, vivendo a morte dos outros, morrendo a vida dos outros". Sendo assim, a experiência da Morte como pensamento e questão ressurge em Max Martins por meio da memória. O poeta percebe também que o movimento contínuo de velamento e desvelo da phýsis não cessa e está acontecendo juntamente com Thánatos, força primordial e impulso da vida.

A relação entre memória e Morte atravessa sua poesia. Ao adentrar na memória, o poeta se confrontará com as sensações advindas da experiência desse télos. Não há como falar de passado sem redimensionar os sentimentos, as angústias. Assim, na poesia martiana, o passado torna-se memória, rememorando a vida, assim como os poetas da Grécia Antiga o fazem, de acordo com o que ilustra Paul Ricoeur (2012, p. 
28), quando interpreta a memória da antiguidade clássica: "Memória: exatamente como quando, à guisa de assinatura, imprimimos a marca de nossos anéis, quando pomos esse bloco de cera sob as sensações e os pensamentos, imprimimos nele aquilo que quereremos recordar". Ao imprimir a vivência do passado em sua poesia, Max Martins engendra outro questionamento latente sobre a Morte, em "Elegia dos que ficaram":

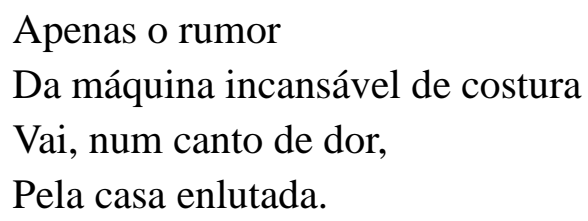

Está toda fechada

E ainda há vagando pela sala

Um perfume suave

De rosa machucada

Mansamente

No quintalejo o vento

Balança

A roupa preta no relento

Sob a lâmpada triste

(tudo é triste neste lar vazio),

Num retrato sorri por entre flores

Aquele que partiu.

Porém rodeando a mesa na varanda,

Recordando os instantes que passaram,

Chora aquela que ficou,

Aqueles que ficaram

(MARTINS, 2001, p. 364).

Neste poema, Max Martins traz a elegia para os que ainda estão vivos, porém ainda há no horizonte o mistério da Morte. No poema podemos ler a dimensão em que a Morte dos outros lança o homem para a angústia, de maneira que o silêncio e o vazio se tornam latentes: “Apenas o rumor /Da máquina incansável de costura/Vai, num canto de dor,/Pela casa enlutada". Apesar das marcas de continuidade do correr do tempo, marcado pelo "rumor" da máquina de costura, o clima, dentro da casa, é de luto. Dessa 
forma, há a vivência da continuação da angústia da Morte após a morte do ente. Apesar de o luto recair em um subjetivismo e quase nulidade em nossa era, diante do que significou no passado, a experiência da Morte reabre ao homem sua manifestação ontológica, pois só o homem vive a Morte, como diz Giorgio Agamben: "Na tradição da filosofia ocidental, com efeito, o homem figura como mortal e, ao mesmo tempo, como falante. Ele é animal que possui a faculdade da linguagem e o animal que possui a faculdade da morte" (AGAMBEN, 2006, p. 10). Os animais apenas findam, pois não têm em seu horizonte a morte como constitutiva das possibilidades do existir na linguagem, o que só acontece com o homem. Os animais findam, só o homem verdadeiramente morre.

Diante disso, Lógos (linguagem) e Thánatos revelam-se como traços fundamentais do homem. Não negando a Morte, na poesia há uma rememoração e, nesta, a conscientização do cumprimento do destino humano em sua história. Segundo Martin Heidegger:

O pensar rememorante distingue-se essencialmente de uma atualização posterior da história no sentido de um transcorrer do passado. A história não acontece no sentido de transcorrer passado. A história não acontece primeiramente como um acontecer e esse acontecimento não é um passar. $\mathrm{O}$ acontecer da história essencializase como o destino da verdade do ser a partir do ser. (2008a, p. 348).

A colocação de Heidegger mostra-nos que o rememorar pensante essencializa o destino do ser devido ao fato de ele estar no mundo, lançado na angústia da morte. Dessa forma, na poesia martiana há uma memória que redimensiona o destino do homem, o qual chega a seu télos no advento da Morte, em detrimento do pensamento que esquece a Morte, tornando-a um conceito, modelo da interpretação da tradição antropocêntrica do real. Portanto, o fim (a morte) é o limiar em que a verdade não se esgota, mas que se orienta para a plenitude da vida:

O manter-se que se contém nos limites, o ter-se seguro a si mesmo, aquilo no que se sustenta o consistente, é o ser do sendo. Faz com que o sendo seja tal em distinção ao não-sendo. Vir à consistência significa, portanto: conquistar limites para si, de-limitar-se. Daí ser um caráter fundamental do sendo o telos, que não diz nem finalidade nem meta ou alvo e, sim, "fim". Mas "fim" não é entendido aqui no sentido negativo, como se alguma coisa já não continuasse e, sim, findasse e cessasse de todo. "Fim" é conclusão no sentido do grau supremo, de plenitude. No sentido de per-feição. Pois bem, limite e fim constituem aquilo em que o sendo principia a ser. São os princípios do ser de um sendo (HEIDEGGER, 1969, p. 88). 
A Morte na obra maxmartiana aparece no horizonte do pensar e do rememorar o destino humano, na forma da angústia, como podemos ler nos versos: "Recordando os instantes que passaram,/ Chora aquela que ficou,/ Aqueles que ficaram" (MARTINS, 2001, p. 364). Dessa forma, a angústia que rege a vida é o lugar em que o homem recebe a dádiva do mistério nas manifestações mais diversas possíveis. O homem já está lançado no vigor das questões e no devir do destino. Ele, então, abre-se para sua essencialização. A Morte sempre está em frente ao homem, pois a estrutura do Dasein já o expõe como sua estrutura essencial. Assim, não se pode retirar a possibilidade do Thánatos da existência em seu devir, já que no mundo o homem já é este ser que detém a possibilidade do mistério e do fundar contínuo, em que a Morte cessa o movimento da Vida em um jogo, assim como nos mostra Heráclito no fragmento 27: "Na morte advém aos homens o que não esperam nem imaginam” (HERÁCLITO,1991, p. 65).

Além disso, Max Martins aponta-nos que tal experiência não se resolve apenas na experiência subjetiva, confinada às representações do homem. Na verdade, hoje percebemos que há uma tendência bastante promovida pela tradição metafísica de reduzir Thánatos a representações subjetivistas. Max Martins propõe que, no morrer, cercear tal questão é propor um afastamento de sua essência, como podemos ver em "De um poema sonhado", da obra 60/35 de 1985:

\title{
Um signo \\ Deserdado da morte
}

$\Psi$

entre ruínas

\author{
A morte \\ (certo os desagrega) \\ só não decifra signos
}

(MARTINS, 2001, 130).

No poema supracitado, percebemos a presença do psi grego. Esse símbolo deu origem à psiché grega, que posteriormente tornou-se psique. Psique nos remete à psicologia, estudo que pretende compreender o comportamento humano. Porém, ao perscrutarmos sua etimologia, a palavra remete ao termo "alma". Entretanto, não pensemos alma dissociada do corpo, do mundo ou como algo divino, mas como a força vital que move o homem aos limites. Em Max Martins, a alma está no plano ontológico, 
haja vista o uso do símbolo grego. Dessa forma, esse "signo", que é a alma, está em ruínas, desfalece. A alma não é vista como eterna. Ela morre e não temos resposta sobre o que é a Morte. Thánatos é fenômeno que arrebata os homens e os faz chegar à plenificação. Porém, não podemos “decifrar” sua imensidão de possibilidades.

Em paralelo, Heráclito, no fragmento 26, aponta-nos para a proximidade constante de Thánatos: "O homem toca a luz na noite, quando com a visão extinta está morto para si; mas vivendo, toca o morto, quando com visão extinta dorme; na vigília toca o adormecido" (HERÁCLITO,1991, p. 65). Dessa forma, podemos perceber que a Morte é um fenômeno que se apresenta na esfera individual, dentro de existências que inauguram o mundo de determinada forma, porém em nenhuma dessas experienciações da Morte é possível ter sua consumação máxima. Assim, a Morte sempre está em um horizonte.

A angústia é um traço fundamental do homem ao experienciar a Morte. O ser-aí encontra-se dentro das possibilidades de existência que lhe foram encobertas pela cotidianidade e pelo senso comum. Max Martins encontra na Morte um mote poético sobre o destino e o acolhimento do mistério que é a vida. A interpretação desse fenômeno em Max Martins mostra-nos que ele se apresenta como o insólito terreno que todos irão habitar, porém também é a experiência em que a vida se torna completa.

\section{Considerações finais}

A obra poética de Max Martins opera a abertura de novos caminhos e de novas intepretações a respeito do fenômeno da Morte, uma vez que a manifesta em novas dimensões as questões humanas em uma lírica única. Em sua poesia, é devolvido ao homem o pensar sobre a finitude, a memória, o passado, fazendo assim uma travessia experimental pelo mundo, buscando viver a experiência inefável da vida. Em verdade, a morte restitui a fluidez e o devir temporal, da dissolução das coisas, da força do tempo, superando a ideia de que o homem é o centro da realidade.

Max Martins propõe pensarmos na Morte em seu sentido originário, restituindo a esse fenômeno seu mistério e tratando-o como fonte de uma poética da experiência do mundo. A poética martiniana contrapõe o sentido desse fenômeno como nulidade, como algo negativo, que decorre devido a uma interpretação metafísica do real, esgotando a morte em um conceito. A plenitude existencial oriunda do télos dá a potência geradora 
da transformação do homem em possibilidades e em contínuo desdobramento com a memória. No morrer o homem pode confrontar sua identidade, seu passado. A Morte em Max Martins é a plenitude existencial se exaurindo, passagem para um novo ciclo.

A morte originária em Max Martins revela ao homem o poder do Ser, voltandose para uma experiência ontológica do mundo, em que o Ser se revela de várias maneiras no mundo, em um devir temporal contínuo. Dessa forma, é restituído ao homem o apelo da linguagem criativa, do pensar e questionar a realidade que o circunscreve, sendo interpretante de sua vida, e não escravo de determinações. A densidade temática da morte e a linguagem fragmentada na poesia martiniana abrem as fraturas da vida ao leitor: a finitude, a saudade, o luto, o cotidiano. Dessa forma, foi possível notar um apelo filosófico sobre a morte que sua obra engendra ao leitor.

No morrer dos outros é possível ao homem experimentar o fenômeno do serpara-morte. Como diálogo, compreendido como entre o lógos, no lógos, também é possível a experimentação desse notável fenômeno do Ser na linguagem poética. Max Martins eleva sua poesia para um pensar sobre esse fenômeno. Em vista disso, a sua obra poética doa-se para a escuta das questões fundadoras da essência humana. A experiência da obra pode ser uma experiência da Morte. A poética é uma experiência em que o homem possui a abertura para a linguagem. Lançado na linguagem, o homem coloca-se diante dos seus limites, da sua finitude posta em evidência na poesia, também podendo experimentar a vida, o renascimento, o constante velar e desvelar da phýsis.

\section{REFERÊNCIAS}

AGAMBEN, G. A Linguagem e a morte: um seminário sobre o lugar da negatividade. Tradução de Henrique Burigo. Belo Horizonte: Editora da UFMG, 2006.

ASSMANN, A. Espaços da recordação: formas e transformações da memória cultural. Tradução de Paulo Soethe. Campinas: Editora da Unicamp, 2011.

BOSI, A. Céu, inferno: ensaios de crítica literária e ideológica. São Paulo: Duas Cidades; Editora 34, 2003.

BRANDÃO, J. Dicionário mítico-etimológico da mitologia grega. Petrópolis, RJ: Vozes, 1991.

FERRAZ, A. O que é uma questão? Revista Litteris - Ciências Humanas - Filosofia, Niterói, RJ, n. 6, p.1-20, nov. 2010. 
HEIDEGGER, M. Introdução à metafísica. Tradução de Emanuel Carneiro Leão. Rio de Janeiro: Tempo Brasileiro, 1969.

Ser e tempo. Tradução de Fausto Castilho. Campinas, SP: Editora da Unicamp; Petrópolis, RJ: Editora Vozes, 2012a.

HERÁCLITO. Os pensadores originários. Tradução de Emmanuel Carneiro Leão e Sérgio Wrublewski. Petrópolis, RJ: Vozes, 1991.

JUNQUEIRA, L. Télos. In: CASTRO, Manuel Antônio (Org). Convite ao pensar. Rio de Janeiro: Tempo Brasileiro, 2014. p. 233 - 234.

LAUWERS, M. O nascimento do cemitério: lugares sagrados dos mortos no ocidente medieval. Tradução de Robson Murilo Grando Della Torre. Campinas, SP: Editora da Unicamp, 2015.

LEÃO, E. Aprendendo e pensar II. Petrópolis: Vozes, 1992.

LE GOFF, J. História e memória. Tradução de Bernardo Leitão. Campinas, SP: Editora da Unicamp, 1992.

LEITÃO, A. A figuração poética do corpo na obra Linha-D'água, de Olga Savary. 2015. - Dissertação (Mestrado em Letras - Estudos Literários) - Programa de PósGraduação em Letras, Universidade Federal do Pará. 